Artikel Penelitian

\title{
HUBUNGAN TINGKAT KEPATUHAN KONSUMSI OBAT ANTI RETRO VIRAL (ARV) PADA PASIEN HIV DENGAN KEJADIAN INFEKSI PROTOZOA USUS DI RSUP DR M DJAMIL PADANG
}

\author{
Nisrina Harmi Sari ${ }^{1}$, Selfi Renita Rusjdi ${ }^{2}$, Eliza Anas $^{3}$
}

\begin{abstract}
Abstrak
HumanImunodeficiency Virus/Acquired Immunodeficiency Syndrome (HIVIAIDS) belum dapat disembuhkan, namun dapat dikendalikan dengan pengobatan Anti Retro Viral (ARV). Ketidak patuhan konsumsi ARV meningkatkan resiko infeksi protozoa usus pada pasien HIVIAIDS dengan CD $4+T$ cell<200 sel/ $\mu$ l. Tujuan penelitian ini adalah untuk menentukan hubungan antara tingkat kepatuhan konsumsi ARV dengan kejadian infeksi protozoa usus di RSUP Dr.M.Djamil Padang. Rancangan penelitian berupa studi potong lintang dengan metode consecutive-sampling. Penelitian ini dilaksanakan di Poliklinik VCT (Volunteer, Conseling and Theraphy) dan bangsal penyakit dalam RSUP Dr.M.Djamil Padang dari bulan Januari hingga April 2017. Sampel penelitian berjumlah 33 pasien HIVIAIDS yang didiagnosis oleh dokter. Hasil penelitian didapatkan umur rerata pasien HIVIAIDS adalah 34.87 tahun. Pasien laki-laki 66.67\%, dan perempuan 33.33\%. Tingkat kepatuhan konsumsi ARV rendah 48.48\%, sedang 9.09\%, dan tinggi $42.42 \%$. Tingkat kepatuhan rendah $13(39.4 \%)$ pasien yang positif terinfeksi protozoa usus dan $3(9.1 \%)$ pasien tidak terinfeksi. Tingkat kepatuhan sedang $2(6.1 \%)$ pasien yang positif terinfeksi dan $1(3 \%)$ pasien tidak terinfeksi. Tingkat kepatuhan tinggi $2(6.1 \%)$ pasien yang positif terinfeksi dan $12(36.4 \%)$ pasien tidak terinfeksi. Berdasarkan uji statistik chi-square menunjukkan terdapat perbedaan bermakna antara tingkat kepatuhan konsumsi ARV dan kejadian infeksi protozoa usus di RSUP Dr M Djamil Padang $(p=0.001)$. Simpulan penelitian adalah terdapat hubungan antara tingkat kepatuhan konsumsi ARV dengan kejadian infeksi protozoa usus pada pasien HIV.
\end{abstract}

Kata kunci: HIVIAIDS, ARV, infeksi protozoa usus

\section{Abstract}

Human Imunodeficiency Virus/Acquired Immuno Deficiency Syndrome (AIDS) can not be cured yet, but it can be controlled by Anti Retro Viral (ARV) treatment. The Non-Adherence of ARV treatment increases intestinal protozoan infection risks in HIVIAIDS patients with CD4+ $T$ cells $<200$ cells/ $\mu l$. The objective of this study was to determine correlation between adherence levels of ARV consumption and intestinal protozoan infection incidences. The design of research is cross-sectional study with consecutive-sampling method. This research was conducted at VCT (Volunteer, Conseling and Theraphy) outpatient and internal medicine ward of Dr.M.Djamil Hospital since January to April 2017. The samples were 33 HIVIAIDS patients which diagnosed by doctors. The results showed HIVIAIDS patients mean age was 34.87 years old. Patients were male $66.67 \%$ and female $33.33 \%$. The low adherence levels of ARV consumption were $48.48 \%$, moderate $9.09 \%$, and high $42.42 \%$. The results of low adherence were $13(39.4 \%)$ infected by intestinal protozoa and 3 (9.1\%) uninfected. Moderate adherence were 2 (6.1\%) infected by intestinal protozoa and 1 (3\%) uninfected. High adherence levels were 2 (6.1\%) infected and 12 (36.4\%)not infected. The chi-square test showed significant differences between adherence levels and incidences of ARV treatment intestinal protozoan infection in Dr.M.Djamil Padang ( $p=0.001)$. This study had proven correlation between ARV treatment adherence with intestinal protozoan infection in HIVIAIDS patients.

Keywords: HIVIAIDS, ARV, intestinal protozoan infection 
Affiliasi penulis: 1. Profesi Dokter FK UNAND (Fakultas Kedokteran Universitas Andalas, 2. Bagian Parasitologi FK UNAND, 3. Bagian Biologi FK UNAND

Korespondensi: Nisrina Harmi Sari, Email: nisrina37@gmail.com, Telp: 082388387915

\section{PENDAHULUAN}

Human Imunodeficiency Virus/Acquired Imunodeficiency Syndome (HIVIAIDS) adalah salah satu infeksi menular seksual yang menjadi masalah besar. Prevalensi di beberapa negara berkembang meningkat setiap tahunnya. Jumlah penderita HIVIAIDS menurut WHO 2014 di seluruh dunia berjumlah 36.9 juta kasus, dimana 34.3 juta kasus pada dewasa, 17.4 juta kasus pada wanita dan 2.6 juta pada anak dibawah 15 tahun. Penderita AIDS yang meninggal pada tahun 2014 di seluruh dunia berjumlah 1.2 juta orang dengan rincian, 1 juta orang dewasa meninggal dan 150.000 anak dibawah 15 tahun meninggal. ${ }^{1}$

Kasus HIVIAIDS tersebar di seluruh dunia. Tahun 2013 UNAIDS melaporkan dengan angka kejadian di Sub-Sahara Afrika berjumlah 24.7 juta kasus, Afrika Utara dan Timur Tengah berjumlah 230.000 kasus, Eropa Timur-Asia Tengah berjumlah 1.1 juta kasus dan Asia-Pasifik berjumlah 4.8 juta kasus, tiga besar negara yang berkontibusi dalam data adalah $51 \%$ kasus berasal dari India, $14 \%$ kasus berasal dari Cina, $12 \%$ kasus berasal dari Indonesia. ${ }^{2}$

Di Indonesia, data kumulatif HIV/AIDS yang dilaporkan 1 Januari 2016-30 Maret 2016 adalah HIV 32.711 kasus dan AIDS 7.864 kasus. Angka penderita HIVIAIDS di Sumatera Barat sejak 1992-2014 sebanyak 932 kasus HIV dan 1.173 kasus AIDS. Kabupaten dan kota dengan jumlah kasus tertinggi adalah Kota Padang 454 kasus, Kota Bukittinggi 168 kasus dan Kabupaten Agam 82 kasus. ${ }^{3,4}$

Infeksi HIVIAIDS ini dapat dikendalikan dengan pengobatan ARV. Jumlah kasus HIV yang selalu bertambah dan banyak yang memasuki stadium AIDS yaitu saat kadar CD4 kurang dari $200 \mathrm{sel} / \mu \mathrm{l}$,mungkin disebabkan karena ketidakpatuhan dalam pengobatan ARV. Kepatuhan pada pengobatan ARV merupakan komponen penting untuk mencapai keberhasilan terapi yang optimal. Kepatuhan terhadap terapi adalah hal yang kritis untuk mendapat manfaat dari terapi ARV termasuk memaksimalkan serta penekanan terhadap replikasi virus, mengurangi kerusakan sel-sel CD4, pencegahan resistensi virus, peningkatan kembali kekebalan tubuh, dan memperlambat perkembangan penyakit. Disarankan kepada ODHA (Orang Dengan HIVIAIDS) penting untuk mengkonsumsi paling sedikit 95\% dosis ARV $(<3$ dosis tidak diminum dalam periode 30 hari pada dosis pengobatan dua kali sehari) dengan cara dan waktu yang tepat agar ARV memiliki potensi terbaik untuk mencapai dan menekan virus HIV. ${ }^{3}$

Resiko terjadinya infeksi protozoa usus meningkat pada pasien HIVIAIDS. Pasien HIVIAIDS yang memiliki CD4+ T cell $<200 \mathrm{sel} / \mu \mathrm{l}$ menjadi mudah terinfeksi protozoa usus dan menyebabkan gejala klinis yang berat, seperti diare bahkan kematian. Protozoa usus jauh lebih sering menyebabkan kematian pada pasien HIV karena menyebabkan diare yang sulit diatasi kejadiannya. Jenis diare yang sering terjadi adalah kriptosporidiasis, giardiasis, dan isosporiasis. Spesies yang tergolong protozoa intestinal yang menyebabkan penyakit pada manusia yaitu kelas Rhizopoda adalah Entamoeba histolitica, kelas Mastigophora adalah Giardia lamblia, dan kelas Sporozoa adalah Isospora hominis sedangkan jenis lain adalah Blastocystis hominis. Terdapat juga jenis protozoa intestinal lain dari kelas Rhizopoda, Balantidium coli dari kelas Ciliata, dan Cryptosporidium parvum serta Cyclospora cayetanesis dari kelas Sporozoa. Sedangkan protozoa usus yang sering menyebabkan penyakit pada pasien HIV adalah Entamoebahistolytica, Giardia lamblia, infeksi oportunistik hanya ditemukan pada pasien yang tidak patuh terhadap terapi ARV yang menyebabkan kadar CD 4 rendah, seperti Crypotosporidiumspp dan Isospora belli. ${ }^{6,7,8, ~ 9, ~ 10, ~} 11$

Hasil penelitian di Yogyakarta, prevalensi infeksi protozoa usus pada pasien HIVIAIDS di RSUP Dr Sardjito Yogyakarta pada bulan Desember 2009 hingga Maret 2010 adalah 81,2\%. Protozoa usus yang ditemukan dalam pemeriksaan tinja adalah Cryptosporidium sp. (60.98\%), Microsporidium sp. (19,51\%), Entamoeba histolytica (9.76\%), Cyclospora cayetanensis $(4,88 \%)$, Blastocystis hominis $(2,44 \%)$ 
dan Giardia lamblia (2,44\%). Penelitian di Hiwot Kasa Specialized University Ethiophia Timur, secara signifikan 33,7\% lebih tinggi kejadian infeksi protozoa usus pada pasien HIV yang tidak patuh terhadap terapi ARV, spesies yang teridentifikasi adalah Entamoebahistolytica (13,5\%), Giardia lamblia (8,1\%), dan spesies Cryptosporidium (2,2\%). ${ }^{6,11}$

Pasien HIV dengan diare dan jumlah CD4 rendah serta tidak mematuhi terapi ARV lebih mudah terinfeksi infeksi protozoa usus daripada mereka yang mempunyai kadar CD4 tinggi dan patuh terhadap terapi ARV. Pemeriksaan tinja pada saat awal dan pengobatan parasit usus pada pasien HIVIAIDS sangat penting. Prevalensi protozoa usus bagi penderita yang tidak patuh terhadap terapi ARV adalah stadium klinis dengan gejala sedang dan berat adalah faktor risiko yang paling dominan untuk infeksi protozoa usus pada pasien HIV / AIDS., ${ }^{6} 11$ Tujuan penelitian ini adalah menentukan hubungan antara tingkat kepatuhan konsumsi ARV dengan kejadian infeksi protozoa usus di RSUP Dr.M.Djamil Padang.

\section{METODE}

Rancangan penelitian berupa studi potong lintang. Sampel penelitian adalah pasien HIVIAIDS yang berobat di Poliklinik VCT dan bangsal Penyakit Dalam RSUP Dr. M.Djamil Padang pada bulan Februari sampai April 2016. Pengambilan sampel menggunakan metode konsekutif. Sampel yang memenuhi criteria inklusi berjumlah 33 orang. Kriteria inklusi dalam penelitian ini adalah pasien yang didiagnosis HIV berkunjung ke Poli VCT dan dirawat di bangsal penyakit dalam RSUP Dr. M. Djamil yang bersedia menjadi responden dan mendapat terapi ARV paling sedikit satu bulan dan bersedia melakukan pemeriksaan tinja.

Kriteria eksklusi dalam penelitian ini adalah pasienyang berkunjung ke Poli VCT dan di rawat di bangsal penyakit dalam RSUP Dr. M. Djamil dengan suspek HIV tetapi setelah dilakukan pengujian tes HIV tidak memenuhi kriteria HIV. Variabel bebas pada penelitian ini adalah Infeksi protozoa usus, sedangkan variabel terikat adalah tingkat kepatuhan ARV pada pasien HIV. Pasien HIVIAIDS didiagnosis oleh dokter, sedangkan pemeriksaan tinja dilakukan di bagian
Laboratorium Parasitologi. Data yang diperoleh diolah secara komputerisasi, kemudian data dianalisis menggunakan uji chi-square.

\section{HASIL}

Subjek penelitian HIVIAIDS banyak ditemukan pada laki-laki, yaitu 22 pasien (66.67\%), perempuan 11 pasien (33.33\%). Umur rerata subjek penelitian adalah 34.87 tahun

Tabel1. Karakteristik sampel penelitian

\begin{tabular}{|c|c|c|}
\hline Karakteristik & $\mathbf{n}$ & $\%$ \\
\hline \multicolumn{3}{|l|}{ Jenis Kelamin } \\
\hline Laki-laki & $22(66.67)$ & $66.67 \%$ \\
\hline Perempuan & $11(33.33)$ & $33.33 \%$ \\
\hline \multicolumn{3}{|l|}{ Usia } \\
\hline$<35$ tahun & 19 (57.57\%) & $57.57 \%$ \\
\hline$\geq 35$ tahun & $14(42.42 \%)$ & $42.42 \%$ \\
\hline
\end{tabular}

Gambaran tingkat kepatuhan konsumsi obat ARV pasien HIVIAIDS RSUP Dr M Djamil Padang. Tingkat kepatuhan tinggi ditemukan pada 14 pasien (42.42\%), tingkat kepatuhan sedang ditemukan pada 3 pasien $(9.09 \%)$ dan tingkat kepatuhan rendah ditemukan pada 16 pasien (48.48\%) seperti diperlihatkan Tabel 2.

Tabel 2. Gambaran tingkat kepatuhan konsumsi ARV pasien HIVIAIDSRSUP Dr M Djamil Padang

\begin{tabular}{|c|c|c|}
\hline \multicolumn{3}{|l|}{ Tingkat } \\
\hline Kepatuhan & $\mathbf{n}$ & $\%$ \\
\hline Rendah & 16 & 48.48 \\
\hline Sedang & 3 & 9.09 \\
\hline Tinggi & 14 & 42.42 \\
\hline Jumlah & 33 & 100 \\
\hline
\end{tabular}

Hasil tingkat kepatuhan rendah terdapat 13 (39.4\%) pasien yang positif terinfeksi protozoa usus dan $3(9.1 \%)$ pasien tidak terinfeksi protozoa usus. Tingkat kepatuhan sedang terdapat $2(6.1 \%)$ pasien yang positif terinfeksi protozoa usus dan $1(3 \%)$ pasien tidak terinfeksi protozoa usus. Sedangkan tingkat kepatuhan tinggi 2 (6.1\%) pasien terinfeksi protozoa usus dan 12 (36.4\%) pasien tidak terinfeksi protozoa usus. Hasil ini menunjukkan tingkat kepatuhan konsumsi ARV rendah dan sedang memiliki kejadian 
infeksi protozoa usus lebih tinggi dibandingkan tingkat kepatuhan konsumsi ARV tinggi. Berdasarkan uji statistik chi-square menunjukkan terdapat hubungan yang bermakna antara tingkat kepatuhan konsumsi ARV dengan kejadian infeksi protozoa usus di RSUP Dr M Djamil Padang dengan nilai p 0.001 ( $p<0.05)$.

Tabel 3. Hubungan tingkat kepatuhan konsumsi Obat ARV pada pasien HIV dengan kejadian infeksi protozoa Usus di RSUP Dr M Djamil

\begin{tabular}{ccccc}
\hline Tingkat & \multicolumn{2}{c}{ KejadianInfeksi } & Nilai \\
\cline { 2 - 3 } Kepatuhan & Positif (+) & $\begin{array}{c}\text { Negatif } \\
(-)\end{array}$ & Total & p \\
\hline Rendah & 13 & 3 & 16 & \\
& $(39.4 \%)$ & $(9.1 \%)$ & $(48.5 \%)$ & \\
Sedang & 2 & 1 & 3 & 0.001 \\
& $(6.1 \%)$ & $(3 \%)$ & $(9.1 \%)$ & \\
Tinggi & 2 & 12 & 14 & \\
& $(6.1 \%)$ & $(36.4 \%)$ & $(42.4 \%)$ & \\
\hline Total & 17 & 16 & & \\
& $(51.5 \%)$ & $(48.5 \%)$ & & \\
\hline
\end{tabular}

\section{PEMBAHASAN}

Subjek penelitian berjumlah 33 pasien HIVIAIDS di poliklinik VCT dan bangsal penyakit dalam RSUP Dr M Djamil dengan umur rerata 34.87 tahun. Hal ini mungkin disebabkan factor resiko paling banyak yang menyebabkan HIVIAIDS di Indonesia adalah pengguna narkoba suntik (penasun) danseksbebas yang sering dilakukan oleh kelompok usia remaja-dewasa awal menurut laporan Kemenkes RI (2013). Hasil penelitian ini relative sama dengan penelitian yang dilakukan Fajrin (2012) di Unit Pelayanan Terpadu HIV RSUPN Dr.Cipto Mangunkusumo tahun 2009 usia remaja-dewasa awal $(61.3 \%)$ lebih besar dari dewasa akhir-manula (38.7\%). Penelitian lain yang dilakukan Nyoko et al (2014) menyatakan kelompok usia remaja-dewasa awal (57.6\%) lebih besar dari kelompok usia dewasa akhir-manula (42.4\%). Karakteristik sampel penelitian HIVIAIDS banyak ditemukan pada pasien laki-laki, 22 orang $(66.67 \%)$, perempuan 11 orang $(33.33 \%)$. Hal ini mungkin disebabkan bahwa telah terjadi pergeseran dimana sebelumnya faktor risiko seks bebas banyak dilakukan oleh wanita pekerja seks (WPS) namun sekarang lebih banyak seks bebas yang dilakukan oleh lelaki berhubungan seks dengan lelaki (LSL) menurut data Kemenkes RI (2013). Hasil penelitian ini relatif sama dengan penelitian yang dilakukan Nyoko et al (2014) bahwa jumlah total jenis kelamin laki-laki yang menderita HIV tahun 2002-2012 di Bali adalah $57,6 \%$, perempuan $42,4 \%$. $^{12,13,14}$

Penelitian ini mendapatkan gambaran tingkat kepatuhan konsumsi obat ARV pasien HIVIAIDS RSUP Dr M Djamil Padang. Tingkat kepatuhan tinggi ditemukan pada 14 pasien $(42.42 \%)$, tingkat kepatuhan sedang ditemukan pada 3 pasien (9.09\%) dan tingkat kepatuhan rendah ditemukan pada 16 pasien (48.48\%). Hal ini mungkin disebabkan perbedaan tingkat kepatuhan konsumsi obat ARV bervariasi tergantung tingkat pengetahuan pasien yang baik, faktor keyakinan terhadap fungsi terapi ARV, fasilitas yang memadai, jarak dan biaya yang ditanggung oleh pasien HIVIAIDS menurut penelitian yang dilakukan Galistiani (2013). Hasil penelitian ini relatif berbeda dengan penelitian yang dilakukan oleh Galistiani 2013 di RSUD Prof. Margono Soekarjo Purwokerto dari 31 pasien. Tingkat kepatuhan tinggi 0 (0\%) sedang $27(87 \%)$ rendah 4 (13\%). Penelitian di India yang dilakukan di India oleh Achappa et al (2013) dengan jumlah pasien 116,64 pasien $(76,2 \%)$ mempunyai tingkat kepatuhan tinggi dan 52 pasien (23.8\%) mempunyai tingkat kepatuhan rendah. ${ }^{5,15}$

Penelitian ini mendapatkan hasil bahwa pasien dengan tingkat kepatuhan rendah terdapat 13 (39.4\%) pasien yang positif terinfeksi protozoa usus dan 3 (9.1\%) pasien tidak terinfeksi protozoa usus. Tingkat kepatuhan sedang terdapat $2(6.1 \%)$ pasien yang positifterinfeksi protozoa ususdan1 (3\%) pasien tidak terinfeksi protozoa usus. Sedangkan tingkat kepatuhan tinggi 2 (6.1\%) pasien terinfeksi protozoa usus dan 12 (36.4\%) pasien tidak terinfeksi protozoa usus. Hasil ini menunjukkan tingkat kepatuhan konsumsi ARV rendah dan sedang memiliki kejadian infeksi protozoa usus lebih tinggi dibandingkan tingkat kepatuhan konsumsi ARV tinggi. Berdasarkan uji statistik chi-square menunjukkan terdapat hubungan yang bermakna antara tingkat kepatuhan konsumsi ARV dengan kejadian infeksi protozoa usus di RSUP Dr M Djamil Padang dengan nilai p 0.001 ( $p<0.05)$. Hal ini mungkin disebabkan karena salah satu cara untuk 
menekan kejadian infeksi pada pasien HIVIAIDS khususnya infeksi protozoa usus yang sering menyebabkan diare dan merupakan salah satu gejala mayor pada pasien HIVIAIDS yaitu dengan meningkatkan kadar sel T CD4 dengan cara meningkatkan kepatuhan konsumsi obat ARV dimana pada pasien dengan tingkat kepatuhan yang buruk lebih sering menderita infeksi protozoa usus dibandingkan pasien yang memiliki tingkat kepatuhan yang baik menurut penelitian yang dilakukan. ${ }^{11,15}$

Hasil penelitian ini sejalan dengan penelitian yang dilakukan di Afrika oleh Adamu dan Petros (2013) dengan jumlah partisipan 371. Pasien yang tidak patuh terhadap terapi ARV sebanyak 112 orang, 51 (45.5\%) orang diantaranya mengalami infeksi protozoa usus. Sedangkan pasien yang patuh terhadap terapi ARV sebanyak 259 orang hanya 74 (28.57\%) orang yang terinfeksi protozoa usus. Hal ini menunjukkan bahwa terdapat hubungan antara kepatuhan konsumsi ARV terhadap kejadian infeksi protozoa usus dengan nilai $p=0.0002{ }^{8}$

\section{SIMPULAN}

Terdapat hubungan yang bermakna antara tingkat kepatuhan konsumsi ARV pada pasien HIVIAIDS dengan infeksi protozoa usus.

\section{DAFTAR PUSTAKA}

1. WHO (World Health Organization). Global HIVIAIDS report; 2015.

2. UNAIDS (United Nations Programme on HIV and AIDS). Epidemiology publications report; 2014.

3. Kementrian Kesehatan Republik Indonesia. Estimasi dan proyeksi HIVIAIDS di Indonesia tahun 2011-2016. Jakarta; 2016.

4. Dinas Kesehatan Provinsi Sumatera Barat. Laporan tahunan 2013. Edisi 2014. Padang; 2014.

5. Galistiani. Kepatuhan pengobatan antiretroviral pada pasien HIVIAIDS di RSUD Prof. Dr. Margono Soekarjo. Media Farmasi. 2011;10(2): 94-103.
6. Resnhaleksmana E, Sutarti E, Wijayanti MA Prevalence and risk factors of intestinal protozoan infection in HIV/AIDS in Dr. Sardjito General Hospital Yogyakarta. Tropical Medicine Journal. 2010;1(1):23-34.

7. Deb M, Joseph A, Khalil S, Mirdha BR, Panda A, Sinha SSY. Intestinal parasitosis in relation to ART, CD4 T-cell count and diarrhea in HIV patients. India; 2015.

8. Adamu H, Petros B. Intestinal protozoan infection among HIV positive person with and without ART in selected ART center in Ethiopia; 2009.

9. Soedarto. Buku ajar parasitologi kedokteran. Jakarta: CV Sagung Seto; 2011.

10. Sutanto I, Ismid IS, Sjarifuddin PK, Sungkar S. Buku Ajar Parasitologi:Balai Penerbit FKUI; 2011.

11. Abate D, Dessie Y, Mitiku H, Teklemarian Z. Prevalence of Intestinal Parasitic Infection Among HIV Positive Who on ART anda Naïve in Hiwot Kasa Specialized University Hospital. Eastern Ethiophia; 2013.

12. Fajrin PNK. Evaluasi terapi ARV terhadap perubahan jumlah CD4 dan berat badan dan terapi OAT terhadap perubahan berat badan pada pasien koinfeksi TB/HIV di Unit pelayanan terpadu HIV RSUPN Dr. Cipto Mangunkusumo (skripsi). Jakarta: Universitas Indonesia; 2012.

13. Nyoko YO, Eka Putra IWG, Sarwitri AAS. Hubungan karakteristik demografi, klinis dan faktor risiko terinfeksi HIV dengan koinfeksi HIV/TB di Klinik Amertha Yayasan Kerti Praja Denpasar. Public Health and Preventive Medicine Archive. Desember 2014;2(2):124-32.

14. Kementrian Kesehatan Republik Indonesia. Estimasi dan proyeksi HIVIAIDS di Indonesia tahun 2011-2016. Jakarta; 2013.

15. Achappa B, Bhaskaran U, Madi D, Mahalingam S, Ramapuram TJ, Rao $S$. Adherence to anti retroviral therapy among people living with HIV. India; 2013. 